\title{
Ethnopharmacological Survey and Antisickling Activity of Plants Used in the Management of Sickle Cell Disease in Kikwit City, DR Congo
}

\author{
Jules Munganga Kitadi, ${ }^{1}$ Prince Pambi Mazasa, ${ }^{2}$ Damien Sha-Tshibey Tshibangu, ${ }^{3}$ \\ Félicien Mushagalusa Kasali $\mathbb{D}^{\mathbb{D}},{ }^{4}$ Dorothée Dinangayi Tshilanda $\mathbb{D}^{\mathbb{D}},{ }^{2}$ \\ Koto-Te-Nyiwa Ngbolua $\mathbb{D}^{2},{ }^{2}$ and Pius Tshimankinda Mpiana ${ }^{3}{ }^{3}$ \\ ${ }^{1}$ University of Kikwit, Kwilu, Kikwit, Democratic Republic of the Congo \\ ${ }^{2}$ Department of Biology, Faculty of Science, University of Kinshasa, P.O. Box 190, Kinshasa, Democratic Republic of the Congo \\ ${ }^{3}$ Department of Chemistry, Faculty of Science, University of Kinshasa, P.O. Box 190, Kinshasa, Democratic Republic of the Congo \\ ${ }^{4}$ Department of Pharmacy, Faculty of Pharmaceutical Sciences and Public Health, Official University of Bukavu, P.O. Box. 570, \\ Bukavu, Democratic Republic of the Congo
}

Correspondence should be addressed to Pius Tshimankinda Mpiana; ptmpiana@gmail.com

Received 23 July 2020; Revised 29 September 2020; Accepted 14 October 2020; Published 26 October 2020

Academic Editor: Monica Borgatti

Copyright (C) 2020 Jules Munganga Kitadi et al. This is an open access article distributed under the Creative Commons Attribution License, which permits unrestricted use, distribution, and reproduction in any medium, provided the original work is properly cited.

\begin{abstract}
Background. Sickle cell disease or drepanocytosis is the most known hemoglobin abnormality in the world. Recently, many medicinal plants used in the management of sickle cell disease in African traditional medicine have shown in vitro antisickling activity. Objective. This research study aims to document some Congolese plant species used in the management of sickle cell disease in Kikwit city and investigate their pharmacological property in vitro. Methods. A cross-sectional survey was done from June 2015 to March 2016 among 26 traditional healers in Kikwit city, Democratic Republic of Congo. Emmel test was used to assess in vitro antisickling activity. Habitat, morphological, biological types, phytogeographical distribution, local names, and used parts of these plant species were also determined. Results. Obtained results show that 23 plant species belonging to 16 families are used. The leaves represent the most used part (70\%). Antisickling investigation showed that aqueous extracts of 18 plants (78\%) exhibit a change in the shape of a sickle cell into a normal one with a normalized rate of at least $70 \%$, confirming the in vivo effect observed by traditional healers when used as herbal medicine traditionally in the management of sickle cell disease. The evaluation of perimeter, surface, and radius of untreated and treated sickle red blood cells showed a significant difference $(p<0.05)$ as modification indicators of the red blood cell shape. Alchornea cordifolia, Alternanthera bettzickiana, Annona senegalensis, Dissotis brazzae, Hypoxis angustifolia, and Justicia secunda presented a very high antisickling activity with normalization $>70 \%$. Otherwise, Dissotis brazzae was the most active plant with a minimal concentration of normalization (MCN) of $11 \mu \mathrm{g} / \mathrm{mL}$ and a maximal normalization rate (NRmax) of $86 \%$. Conclusion. Almost $80 \%$ of the plants studied showed interesting antisickling activity and justified their use in traditional medicine. The isolation of the molecules responsible for the biological activity of the most active plants and the determination of their chemical structures is under investigation.
\end{abstract}

\section{Introduction}

Sickle cell disease (SCD), also called sickle cell anemia or drepanocytosis, is one of the most common hemoglobin abnormalities in the world [1-5]. About 50 million people are affected in the world, mainly sub-Saharan Africans and their immigrants, especially to America. Nevertheless, this hemoglobin disease is also found in some parts of India and Saudi Arabia [6-8]. In certain African regions, carriers of S hemoglobin can reach $20 \%$ of the population with a prevalence of $25-30 \%$ in Central Africa, including the Democratic Republic of the Congo (RDC). Indeed, in the DRC, 
about a million and a half people are affected by this genetic disease [9-12].

SCD is a painful disease due to a genetic mutation conducting to the substitution of a polar amino acid (glutamic acid) by a nonpolar one (valine) on the sixth position of the beta-globin chain [13]. This change decreases the affinity of hemoglobin for oxygen. Furthermore, this structural modification influences the solubility of hemoglobin conducting abnormal hemoglobin, hemoglobin $\mathrm{S}$ $(\mathrm{HbS})$, to polymerize inside the erythrocytes into a gel or further into fibers, causing the change of the red blood cell (RBC) shape from the normal biconcave form into the sickle form in hypoxic conditions. The HbS polymerization and the sickling of the $\mathrm{RBC}$ are responsible for sickle cell disease to basic pathological processes, the painful vaso-occlusive crises, and chronic hemolytic anemia. The occlusion of microvessels' circulation leads to chronic tissue ischemia and infarction affecting the bone, lungs, brain, kidneys, or spleen that conduct to complications in sickle cell disease [13-15].

Many therapeutic approaches are proposed to relieve sickle cell disease patients from this painful and chronic disease. These include the medullary transplantation, repeated blood transfusion, and the use of hydroxyurea. These approaches are unfortunately ineffective, expensive for the African population, or present high risk of transmission of other infections $[13,15,16]$. Therefore, there is a need for more affordable and effective treatments for this disease. Medicinal plants and traditional medicine seem to offer an adapted solution to African populations. In fact, according to the World Health Organization (WHO), $80 \%$ of the world's population, mainly in Africa, use medicinal plants for some aspects of primary health care $[17,18]$. The DRC is by far the African country with the highest biodiversity with richest flora in the world. Surveys conducted by our research team around big cities revealed more than 120 medicinal plants used in traditional medicine in the management of SCD $[4-6,14,19-29]$.

The present study aims to document and investigate in vitro the medicinal plants used in Congolese traditional medicine in the management of SCD in Kikwit city.

\section{Materials and Methods}

2.1. Study Area. The survey was conducted in Kikwit city, province of Kwilu, located in the southwest part of the Democratic Republic of the Congo at $500 \mathrm{~km}$ west of the capital city Kinshasa (Figure 1). Kikwit's population was estimated to be $1,000,000$ inhabitants in a total area of $92 \mathrm{~km}$ [19].

2.2. Ethnopharmacological Survey. The ethnopharmacological survey was carried out from June 2015 to March 2016. Twenty-six traditional healers from different ethnic groups were identified and questioned on a voluntary basis following the principles laid out in the Declaration of
Helsinki with minor modification [20]. The data checklist was divided into three sections:

Personal information such as name, age, sex, marital status, ethnic group of the informant, and study level Plant data (scientific and vernacular names, village survey, parts used, and the method of harvesting stage or degree and organ development)

Plant therapy data: methods of preparation and administration (transaction and pharmaceutical form, concentration of the organ dose, frequency of taking, and instructions)

The identification of collected plants was carried over by comparison with vouchers referenced at the herbarium of Faculty of Sciences, University of Kinshasa. Voucher specimens are on deposit at the same herbarium.

2.3. Floristic Characterizations of Collected Plants. The collected medicinal plants are characterized by their biological, morphological, and habitat types and by their phytogeographical distribution $[17,21]$. The following biological types were selected: mesophanerophytes $(\mathrm{MsPh})$, microphanerophytes $(\mathrm{McPh})$, nanophanerophytes $(\mathrm{NPh})$, chamaephytes (Ch), therophytes (Th), therophytes scapose (Tsc), erected chamaephytes (Ch er), climbing chamaephytes (Ch $\mathrm{cl})$, and geophytes $(\mathrm{G})$.

The morphological types inventoried are tree $(\mathrm{T})$, shrub (Sh), subshrub (Ssh), annual herb (Ah), vivace herb (Vh), perennial herb $(\mathrm{Ph})$, and liana $(\mathrm{L})$.

Habitat types are distributed as follows: cultured (Cult), subspontaneous cultured (Cult ssp), forest (Fo), fallow (Fal), and ruderal (Rud).

The phytogeographical types of distribution are Afrotropical (AT), Bas-Guineo-Congolese (BGC), GuineoCongolese (GC), Guineo-Congolese-Zambezean (GCZ), and pantropical (Pan).

2.4. Evaluation of Use Value and Informant Consensus Factor Value. Use value (UV) that evaluates the relative importance of each medicinal species based on its relative use among informants was calculated using the following formula:

$$
\mathrm{UV}=\frac{U_{i}}{N_{i}},
$$

where $U_{i}$ is the number of use reports cited by each informant for a given plant species when $N_{i}$ is the total number of informants interviewed for a given plant species.

The usage value agreement is defined as the relative importance of each plant type known to be used as herbal medicine. This index is useful in identifying plants with the highest use (most frequently mentioned) in the treatment of a disease with a given informant consensus factor (ICF) value. ICF (ranging from 0 to 1 ) is used to deduce the homogeneity in the data on the use of a specific plant to treat a certain disease. The informant consensus factor value was calculated using the following formula: 


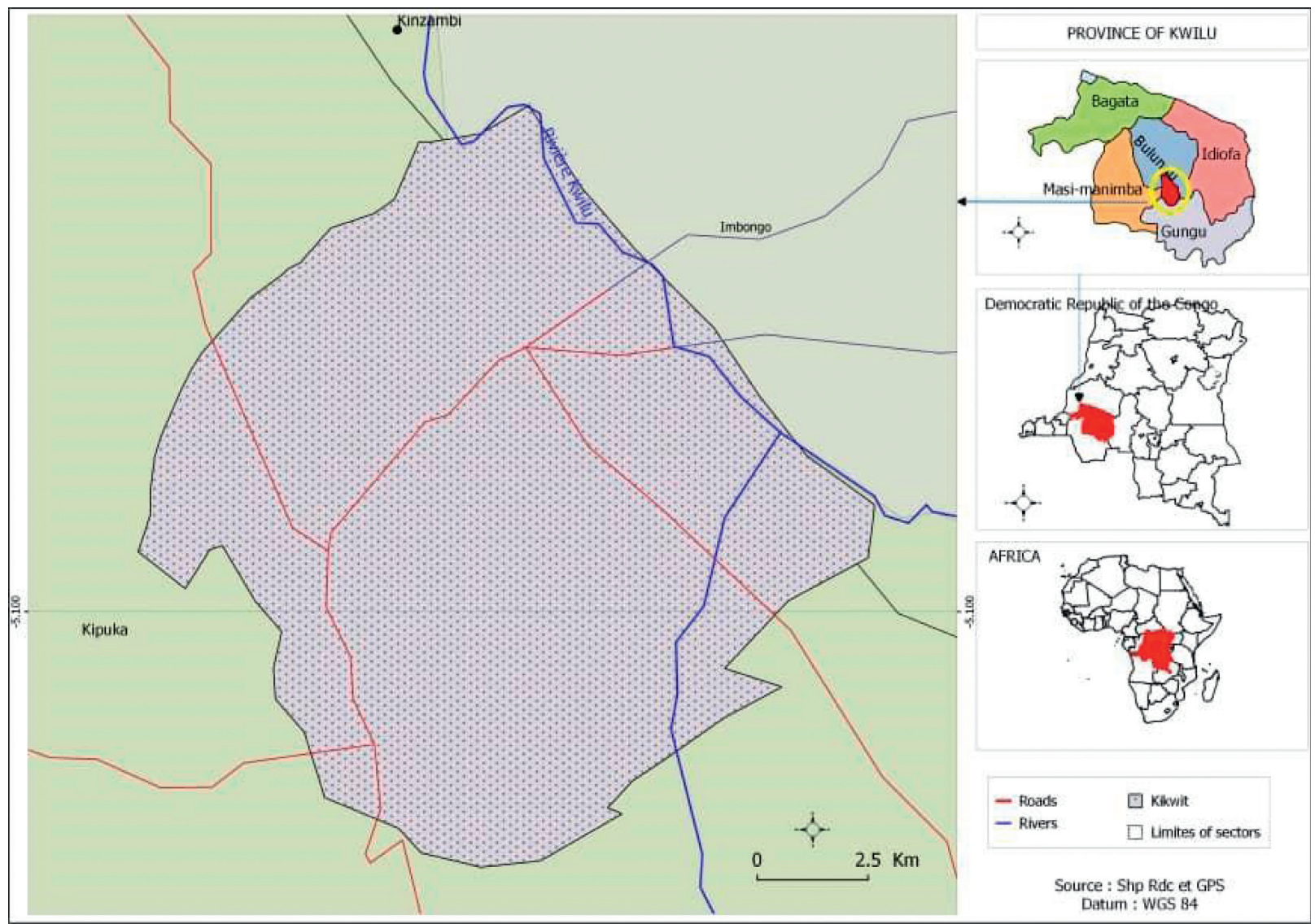

FIgURE 1: Kikwit city in the Democratic Republic of the Congo.

$$
\mathrm{ICF}=N_{c}-\frac{N_{\mathrm{ps}}}{N_{c}-1},
$$

where $N_{c}$ is the number of plant use reports (citation number) per each category and $N_{\mathrm{ps}}$ is the number of plant species (taxa used). A high value of ICF (close to 1) shows that a reduced number of plant species are quoted by a large number of informants for a specific type of treatment, indicating the consistence of the use of this medicine [22].

2.5. Biological Samples. Blood samples used for antisickling evaluation were collected from known sickle cell disease patients treated in Centre de Médecine Mixte et d'Anémie SS in Kinshasa, DRC. None of the patients had been transfused recently with $\mathrm{Hb} \mathrm{AA}$ blood. All antisickling experiments were conducted with freshly collected blood. In order to confirm their SS nature, the aforementioned blood samples were first characterized by hemoglobin electrophoresis on cellulose acetate gel, as previously reported $[7,8,14]$. They were found to be $S S$ blood and were then stored at $\pm 4^{\circ} \mathrm{C}$ in a refrigerator. Informed consent was obtained from all the patients selected in the study. Ethical clearance for the use of sickle blood cells was strictly observed according to international rules.

2.6. Antisickling Assay. Antisickling assay was carried out using Emmel test as previously reported [6, 9, 18]. In brief, sickle cell blood was diluted with $150 \mathrm{mM}$ phosphate buffer saline $\left(\mathrm{NaH}_{2} \mathrm{PO}_{4} 30 \mathrm{mM}, \mathrm{Na}_{2} \mathrm{HPO}_{4} 120 \mathrm{mM}\right.$, and $\mathrm{NaCl}$ $150 \mathrm{mM}$ ) and mixed with an equivalent volume of $2 \%$ sodium metabisulfite. A drop of the mixture was spotted on a microscope slide in the presence of aqueous plant extracts and covered with a cover slip. Physiologic solution was used as the negative control when parahydroxybenzoic acid was used as the positive control. Paraffin was applied to seal the edges of the cover slip completely to create hypoxia condition.

2.7. Data Analysis. Different parameters have been screened in red blood cells, including the area, perimeter, and radius of each RBC using a computer-assisted image analysis system (Motic Images 2000, version 1.3; Motic China Group Co., Ltd), and statistical data analysis was processed using Microcal Origin 8.5 package software.

\section{Results and Discussion}

3.1. Ethnobotanical Analysis. Table 1 summarizes families, species, vernacular names, used parts, and use values of plants used in the management of sickle cell disease in Congolese traditional medicine in Kikwit city.

23 plant species from 16 botanical families cited in different local names, especially Kikongo (sometimes in Lingala and rarely in French), are used in the management of 
Table 1: Plants used in the management of sickle cell disease in Kikwit.

\begin{tabular}{|c|c|c|c|c|c|}
\hline Family & Plant species & Vernacular name & Used part & $\begin{array}{l}\text { Use } \\
\text { value }\end{array}$ & FCI \\
\hline \multirow{2}{*}{ Acanthaceae } & Justicia secunda Vahl. & Matiti ya ba témoins de Jéhovah (Lingala) & Leaves & 3.58 & 0.58 \\
\hline & Rungia grandis T. Ander & - & Bark & 3.34 & 0.55 \\
\hline Amaranthaceae & $\begin{array}{c}\text { Alternanthera bettzickiana repens (L.) } \\
\text { Link }\end{array}$ & Matiti ya ba témoins de Jéhovah (Lingala) & Leaves & 5.12 & 0.68 \\
\hline Annonaceae & Annona senegalensis Pers. & Kilolo, nlolo (Kikongo) & Leaves & 4.12 & 0.58 \\
\hline Bombaceae & Ceiba pentandra (L.) Gaertn. & $\begin{array}{c}\text { Kapokier, fromager (French), mfuma } \\
\text { (Lingala) }\end{array}$ & Leaves & 4.00 & 0.63 \\
\hline Caricaceae & Carica papaya L. & Payipayi (Lingala) & $\begin{array}{l}\text { Leaves, } \\
\text { fruit }\end{array}$ & 5.00 & 0.68 \\
\hline \multirow{3}{*}{ Euphorbiaceae } & Alchornea cordifolia Müll. Arg. & Mbunji-mbunji (Lingala), kibunsi (Kikongo) & Leaves & 4.56 & 0.7 \\
\hline & Bridelia ferruginea Benth. & Kimuindu ki nseke (Kikongo) & Leaves & 3.67 & 0.72 \\
\hline & Vigna unguiculata (L.) Welp. & Mbwengi (Lingala, Kikongo) & Seeds & 4.34 & 0.68 \\
\hline Fabaceae & Millettia laurentii De Wild & $\begin{array}{c}\text { Koboto (Kikongo), ntoka (Kikongo), wenge } \\
\text { (Lingala) }\end{array}$ & Leaves & 4.22 & 0.62 \\
\hline Hypoxidaceae & Hypoxis angustifolia Lam. & $\begin{array}{c}\text { Ditungulu ya mfinda (kikongo), litungulu } \\
\text { (Lingala) }\end{array}$ & Bulbs & 4.00 & 0.63 \\
\hline Lamiaceae & $\begin{array}{c}\text { Leocus africanus (Bak. ex. Elliot) J. K. } \\
\text { Morton }\end{array}$ & Zangazanga (Kikongo) & Bark & 4.89 & 0.65 \\
\hline Melastomataceae & Dissotis brazzae Cogn. & Mampa ya mfinda (Kikongo) & Leaves & 4.45 & 0.67 \\
\hline \multirow[t]{2}{*}{ Mimosaceae } & Albizia ferruginea (Guill. et Piero) Benth. & Sela (Kikongo) & Bark & 4.22 & 0.68 \\
\hline & Treculia africana Decne & Ngungi (Kikongo) & & 3.78 & 0.58 \\
\hline \multirow[t]{2}{*}{ Moraceae } & Ficus asperifolia müg & Kikuya, kuya (Kikongo) & Leaves & 3.89 & 0.64 \\
\hline & Ficus tremula Warb. & - & Leaves & 4.34 & 0.63 \\
\hline Nyctaginaceae & Bougainvillea sp comm. ex Juss & Bintuntu ya nzanguka (Kikongo) & Leaves & 4.67 & 0.63 \\
\hline Phyllanthaceae & Hymenocardia acida Tul & Dikasu, kigete, ngete (Kikongo) & Leaves & 4.67 & 0.59 \\
\hline \multirow{3}{*}{ Rubiaceae } & $\begin{array}{c}\text { Gardenia leopoldiana De Wild \& } \\
\text { T. Durand }\end{array}$ & 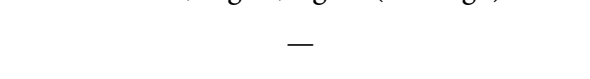 & Bark & 4.89 & 0.65 \\
\hline & Morelia Senegalensis A. Rich. ex DC & - & Leaves & 4.56 & 0.65 \\
\hline & Stipularia africana P. Beauv. & - & Leaves & 4.00 & 0.63 \\
\hline Sterculiaceae & Sterculia bequaertii De Wild & Mvungela mfinda (Kikongo) & Seeds & 3.44 & 0.54 \\
\hline
\end{tabular}

sickle cell disease in Kikwit city. Figures 2 and 3 give the number of species by family used parts, respectively.

According to the results (Figure 2), Rubiaceae and Moraceae families have been represented by three species. However, three families including Euphorbiaceae, Acanthaceae, and Fabaceae had two species, each one and the remaining possessing only one plant species by family.

Figure 3 shows that leaves represent the most used part (66.6\%) when barks represent $16.6 \%$. The use of leaves could be justified by the abundance of chemical groups they contain. In fact, leaves are known as the main synthesis site of secondary metabolites in plants and are the most commonly used plant parts by traditional medicinal practitioners $[17,21]$.

3.2. Use Value. Eight plants (Justicia secunda, Vigna unguiculata, Alternanthera bettzickiana, Alternanthera bettzickiana, Carica papaya, Annona senegalensis, Alchornea cordifolia, and Hypoxis angustifolia) have presented a use value higher than 0.6. They are the most cited plants, and therefore, they are the most used plants in the management of sickle cell disease in Kikwit. According to previous antisickling studies, all cited plant species, except Alternanthera bettzickiana and Hypoxis angustifolia, are well known [4-6, 14, 23-33].
Alternanthera bettzickiana repens (L.) Link displayed both high UV and a large consensus of use among traditional healers indicating the consistence of the use of this plant species as antisickling medicine.

3.3. Ecological Status of Plant Species. Ecological characteristics of these plants are given in Table 2.

3.4. Habitat Types. Types of habitat are presented in Figure 4 . This figure shows that the main habitat type of plants used in the management of sickle cell by traditional healers in Kikwit is forest (39.1\%) followed, respectively, by cultured $(26.1 \%)$ and savanna $(21.7 \%)$. Fallow, ruderal, and subspontaneous cultured represent each one $4.3 \%$.

3.5. Morphological Types. Figure 5 represents morphological types of used plants. Shrub represents the most morphological types (34.8\%) followed by tree (26.1\%), subshrub $(17.4 \%)$, and annual herb (8.7\%). Vivace herb and perennial herb both represent $13 \%$. Furthermore, 14 plant species, up to 23 representing $61 \%$ of species, are trees or shrubs. Only five plant species $(21 \%)$ are herbs. Thus, a correct use of leaves of these plants can permit a sustainable exploitation of these species in traditional medicine. 


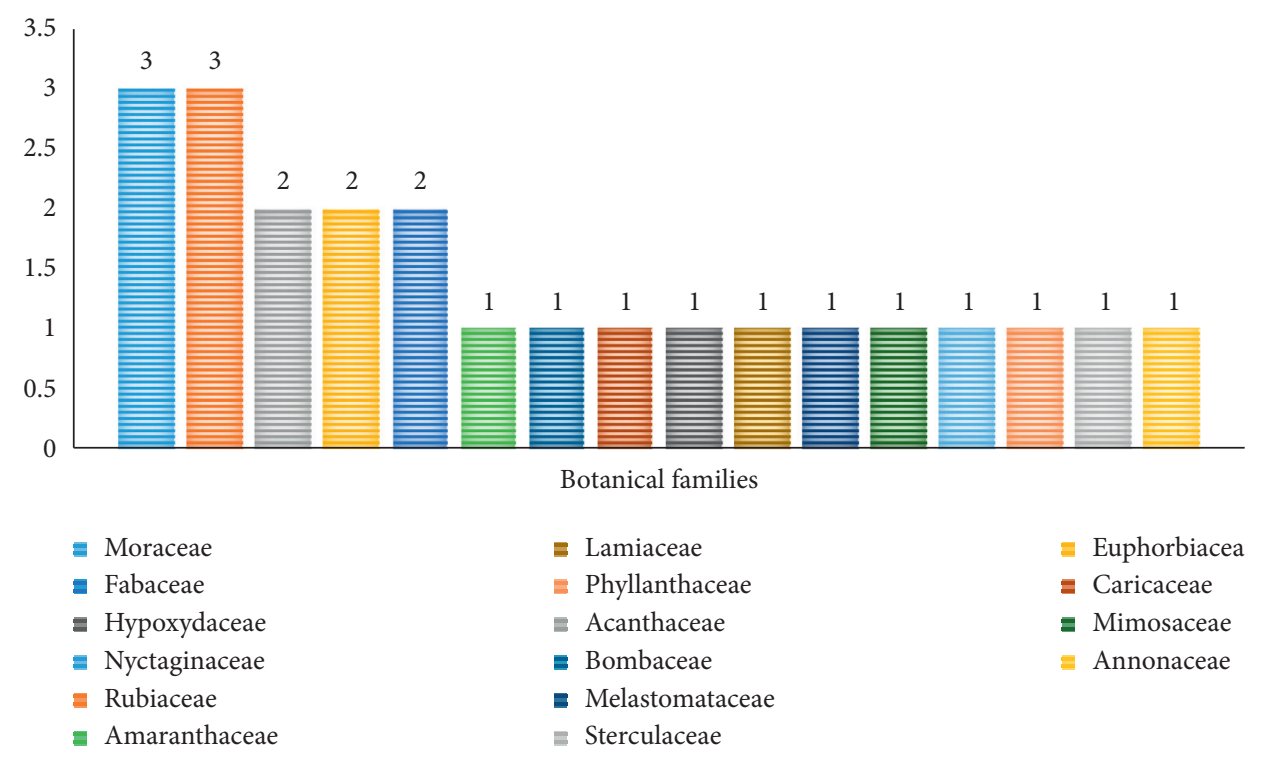

FIgURE 2: Distribution of species by family.

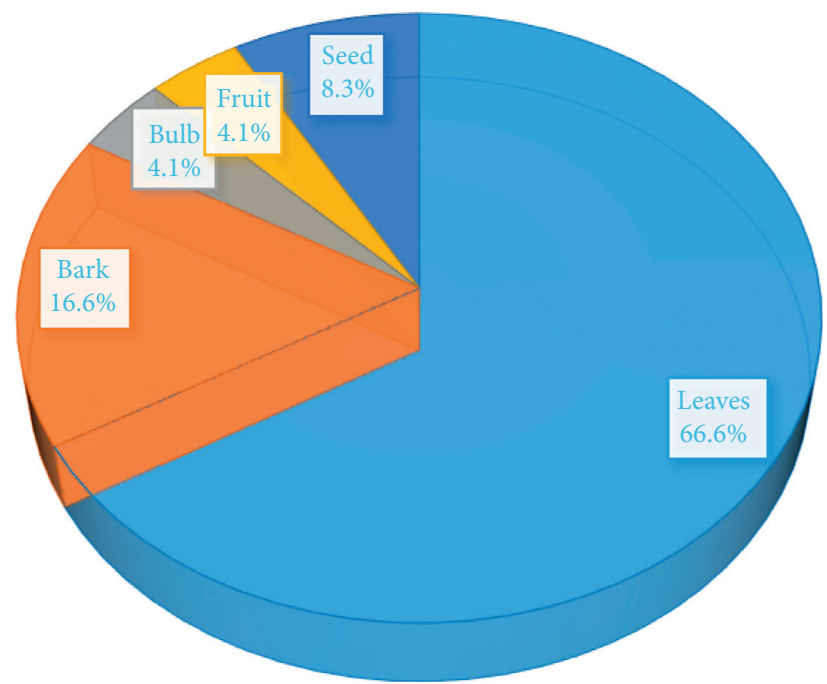

FIgUre 3: Percentage of used parts of plants.

3.6. Biological Types. Biological types are listed in Table 2 and presented in Figure 6.

3.7. Phytogeographical Distribution. Phytogeographical distribution of plants species is given in Figure 7.

Microphanerophyte is the main biological type and represents $43.5 \%$ of identified plant species. Pantropical represents the most phytogeographical distribution (47.8\%).

3.8. In Vitro Antisickling Activity. The results of antisickling evaluation in vitro are represented in Figures 8-11. Figures 8 and 9 represent microscopic images of negative and positive controls when Figures 10 and 11 show morphologies of RBC treated with aqueous plant extracts, Alternanthera bettzickiana, and Dissotis brazzae, respectively.
Figure 8 indicates that the majority of red blood cells is sickled. It means and supports that collected blood is from the sickle cell disease patient. Figure 9 indicates that all blood cells have a normal circular form due to the normalization effect of the positive control.

Figures 10 and 11 show that, in the presence of $D$. brazzae and $A$. bettzickiana aqueous extracts, red blood cells (RBCs) have a circular (biconcave) and normal shape indicating the antisickling effect of these extracts. This situation, in vitro activity, confirms the in vivo effect observed by traditional healers when using an aqueous decoction of these medicinal plants in the management of sickle cell disease in Kikwit city.

The same antisickling activity was found in the other 21 medicinal plants used in the management of sickle cell disease in Kikwit (Table 3).

Table 3 shows that 18 plants (78\%) permit a change of shape of a sickle cell into a normal one with a normalized 
TABLE 2: Ecological status of plants used in the management of sickle cell disease in Kikwit.

\begin{tabular}{|c|c|c|c|c|}
\hline Plant species & HT & MT & BT & $\mathrm{PD}$ \\
\hline Justicia secunda Vahl & Cult & Vh & Nph & Pan \\
\hline Rungia grandis T. Ander & Fo & Vh & $\mathrm{Ch}$ & Pan \\
\hline Alternanthera bettzickiana repens (L.) Link & Cult & $\mathrm{Ah}$ & Nph & Pan \\
\hline Annona senegalensis Pers. & Sav & Sh & Mcph & AT \\
\hline Ceiba pentandra (L.) Gaertn. & Cult ssp & $\mathrm{T}$ & Mgph & Pan \\
\hline Carica papaya L. & Cult & $\mathrm{T}$ & Mcph & Pan \\
\hline Alchornea cordifolia Müll. Arg. & Fo & $\mathrm{Sh}$ & Mcph & AT \\
\hline Bridelia ferruginea Benth. & Sav & Sh & Mcph & GCZ \\
\hline Vigna unguiculata (L.) Welp. & Cult & $\mathrm{Ah}$ & $\mathrm{Th}$ & AT \\
\hline Millettia laurentii De Wild & Fo & $\mathrm{T}$ & Mgph & BGC \\
\hline Hypoxis angustifolia Lam. & Cult & $\mathrm{Ph}$ & G & Pan \\
\hline Leocus africanus (Bak. ex. Elliot) J. K. Morton & Sav, & Ssh & Mcph & GC \\
\hline Dissotis brazzae Cogn. & Rud & Ssh & $\mathrm{Th}$ & Pan \\
\hline Albizia ferruginea (Guill. et Piero) Benth. & Sav & $\mathrm{T}$ & Msph & GC \\
\hline Treculia africana Decne & Fo & $\mathrm{T}$ & Msph & Pan \\
\hline Ficus asperifolia Müg & Fo & Ssh & Lph & BGC \\
\hline Ficus tremula Warb. & Fo & Sh & Mcph & GC \\
\hline Bougainvillea sp comm. Ex Juss & Cult & $\mathrm{Sh}$ & Lph & Pan \\
\hline Hymenocardia acida Tul & Sav & Sh & Mcph & AT \\
\hline Gardenia leopoldiana De Wild \& T. Durand & Fo & Sh & Mcph & $\mathrm{AT}$ \\
\hline Morelia senegalensis A. Rich. Ex DC & Fo & Sh & Mcph & Pan \\
\hline Stipularia africana P. Beauv. & Fal & Ssh & Mcph & Pan \\
\hline Sterculia bequaertii De Wild & Fo & $\mathrm{T}$ & Mgph & GC \\
\hline
\end{tabular}

HT: habit types, MT: morphological types, BT: biotope types, PD: phytogeographical distribution, Cult: cultured, Cult ssp: subspontaneous cultured, Fo: forest, Fal: fallow, Rud: ruderal, T: tree, Sh: shrub, Ssh: subshrub, Ah: annual herb, Vh: vivace herb, Ph: perennial herb, PsPh: mesophanerophytes, McPh: microphanerophytes, NPh: nanophanerophytes, Ch: chamaephytes, Th: therophytes, G: geophytes, AT: Afro-tropical, BGC: Bas-Guinea-Congolese, GC: Guinea-Congolese, GCZ: Guinea-Congolese-Zambezean, and Pan: pantropical.

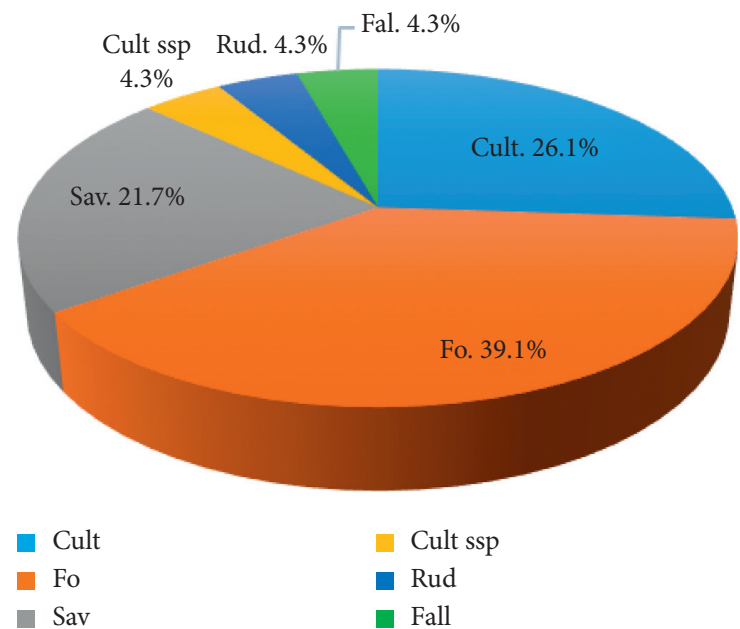

Figure 4: Habitat types of plant species.

rate of at least $70 \%$. This indicates that the information given by traditional healers is validated by in vitro tests. The same results were found in plants used in the management of sickle disease in other Congolese cities [4-6,14,23-33].

Six of these plants (Alchornea cordifolia Müll. Arg., Annona senegalensis; Carica papaya; Hymenocardia acida; Justicia secunda; and Vigna unguiculata) were already cited elsewhere by Congolese traditional healers in the management of sickle cell disease, and they have shown in vitro antisickling activities [4-6, 14, 23-33].

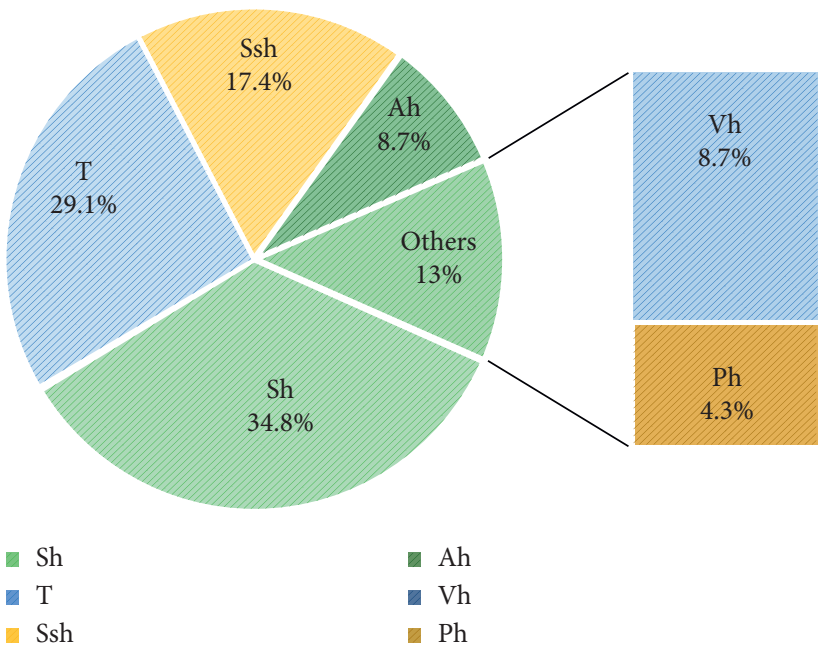

FIGURE 5: Morphological types of plants species.

Table 4 gives use values of medicinal plants used in the management of sickle cell disease in Kikwit city.

Hypoxis angustifolia Lam., Hymenocardia acida Tul, and Vigna unguiculata (L.) Welp are among the most cited species in Kikwit.

In order to quantify the observed shape modification, perimeter, surface, and radius of untreated and treated sickle RBCs with plant extracts were evaluated.

Table 5 shows calculated sickle red blood cell perimeter, surface, and radius modification after treatment of D. brazzae and A. bettzickiana aqueous leaves' extracts. 


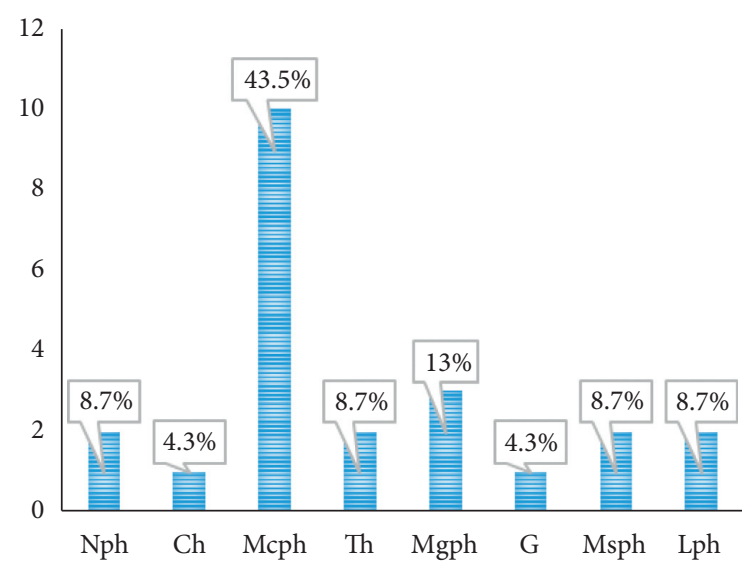

FIGURE 6: Biological types of plant species.

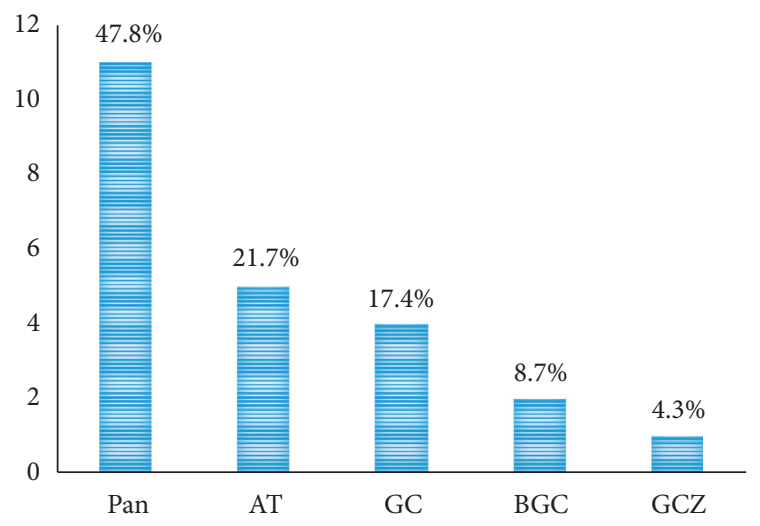

FIgURE 7: Phytogeographical distribution of plants.

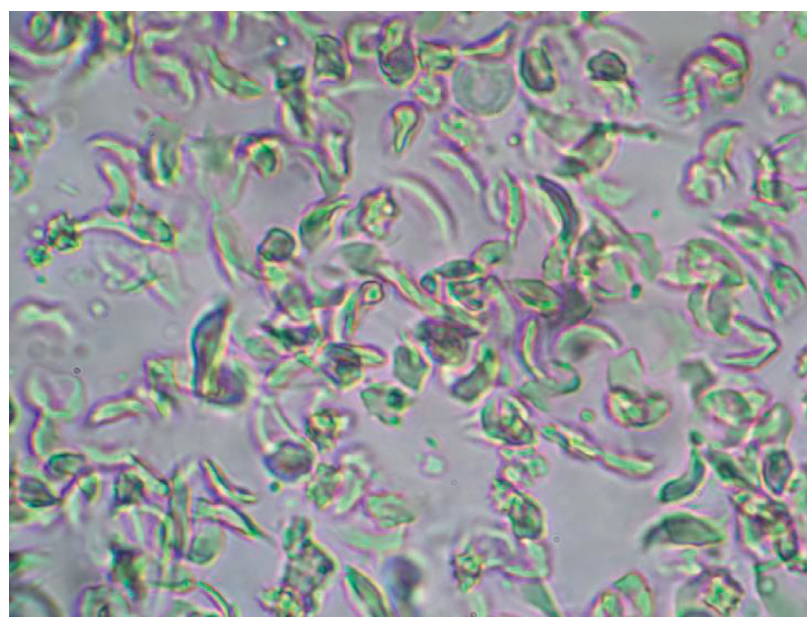

FIGURE 8: Erythrocytes' morphology of untreated sickle cell blood (only saline solution, negative control) (x500) $\left(\mathrm{NaCl} 0.9 \% ; \mathrm{Na}_{2} \mathrm{~S}_{2} \mathrm{O}_{4}\right.$ $2 \%)$.

Values (means \pm S.D) in Table 5 show a significant difference $(p<0.05)$ between the negative control compared to values from the two extracts. This confirms the antisickling activity of these plant aqueous extracts. Furthermore, the values obtained from the two plant extracts are in

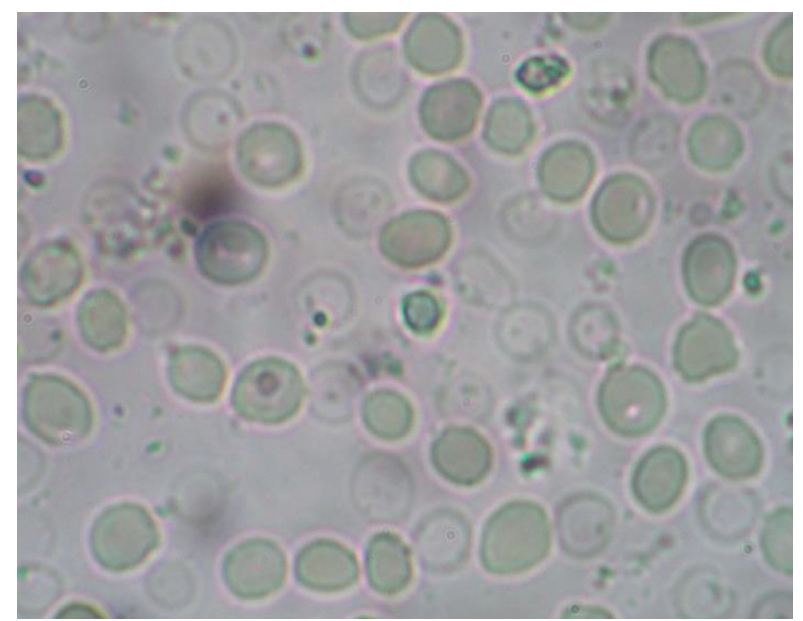

FIGURE 9: Erythrocytes' morphology of sickle cell blood in the presence of parahydroxybenzoic acid $(0.8 \mu \mathrm{g} / \mathrm{mL})(\mathrm{x} 500)(\mathrm{NaCl}$ $\left.0.9 \% ; \mathrm{Na}_{2} \mathrm{~S}_{2} \mathrm{O}_{4} 2 \%\right)$.

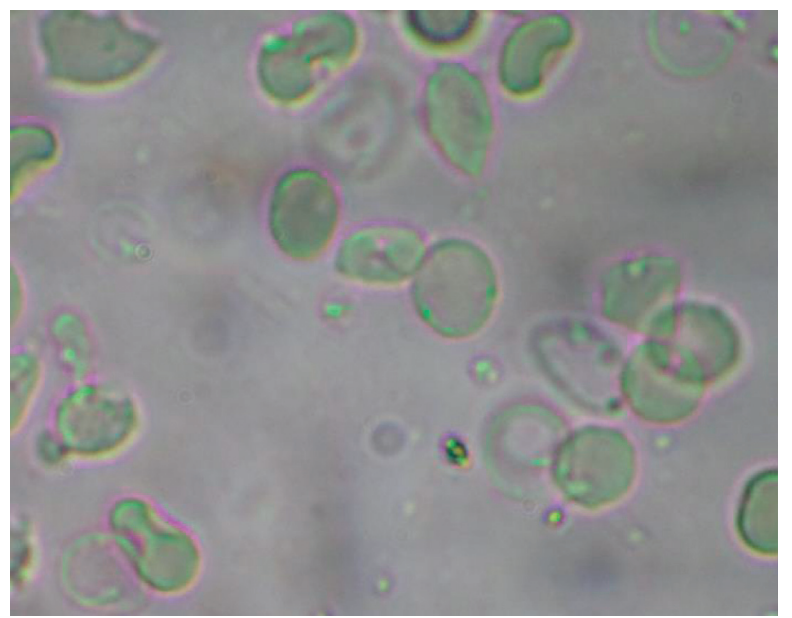

FIGURE 10: Erythrocytes' morphology of sickle cell blood in the presence of the aqueous leaves' extract of Dissotis brazzae $(20 \mu \mathrm{g} /$ $\mathrm{mL})(\mathrm{x} 500)\left(\mathrm{NaCl} 0.9 \% ; \mathrm{Na}_{2} \mathrm{~S}_{2} \mathrm{O}_{4} 2 \%\right)$.

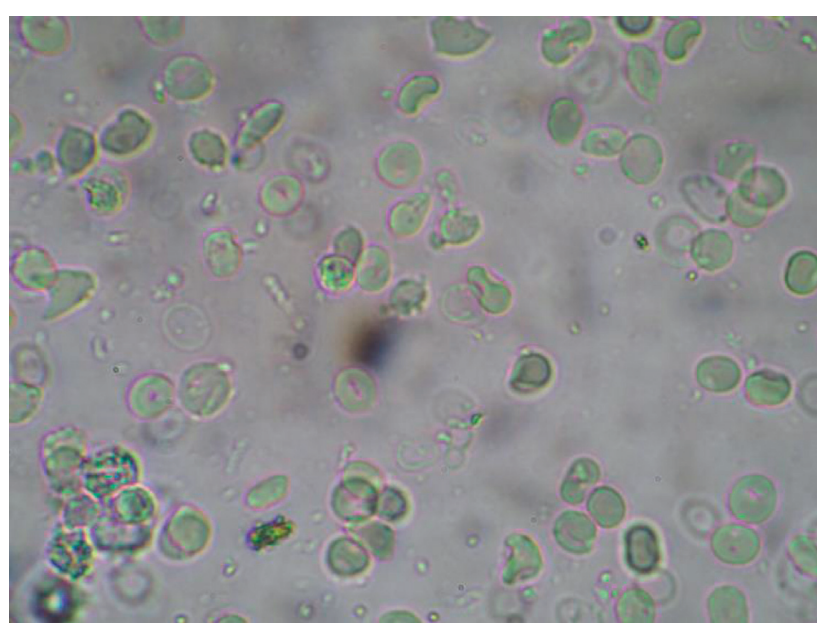

FIGURE 11: Erythrocytes' morphology of sickle cell blood in the presence of the aqueous leaves' extract of Alternanthera bettzickiana leaves $(20 \mu \mathrm{g} / \mathrm{mL})(\mathrm{x} 500)\left(\mathrm{NaCl} 0.9 \%\right.$; $\left.\mathrm{Na}_{2} \mathrm{~S}_{2} \mathrm{O}_{4} 2 \%\right)$. 
TABLE 3: In vitro antisickling activity of plant species used in the management of sickle cell disease in Kikwit.

\begin{tabular}{|c|c|c|}
\hline $\mathrm{N}^{\circ}$ & Plant species & Antisickling activity \\
\hline 1 & Albizia ferruginea (Guill. et piero) Benth. & + \\
\hline 2 & Alchornea cordifolia Müll. Arg. & +++ \\
\hline 3 & Alternanthera bettzickiana repens (L.) Link & +++ \\
\hline 4 & Annona senegalensis Pers. & +++ \\
\hline 5 & Bougainvillea sp comm. Ex Juss & + \\
\hline 6 & Bridelia ferruginea Benth. & ++ \\
\hline 7 & Carica papaya $\mathrm{L}$ & ++ \\
\hline 8 & Ceiba pentandra (L.) Gaertn. & + \\
\hline 9 & Dissotis brazzae Cogn. & +++ \\
\hline 10 & Ficus asperifolia Müg & ++ \\
\hline 11 & Ficus tremula Warb. & ++ \\
\hline 12 & Gardenia leopoldiana De Wild \& T. Durand & + \\
\hline 13 & Hymenocardia acida Tul & ++ \\
\hline 14 & Hypoxis angustifolia Lam. & +++ \\
\hline 15 & Justicia secunda Vahl & +++ \\
\hline 16 & Leocus africanus (Bak. ex. Elliot) J. K. Morton & ++ \\
\hline 17 & Millettia laurentii De Wild & + \\
\hline 18 & Morelia senegalensis A. Rich. ex DC & ++ \\
\hline 19 & Rungia grandis T. Ander & ++ \\
\hline 20 & Sterculia bequaertii De Wild & ++ \\
\hline 21 & Stipularia africana P. Beauv. & ++ \\
\hline 22 & Treculia africana Decne & ++ \\
\hline 23 & Vigna unguiculata (L.) Welp & +++ \\
\hline
\end{tabular}

$+++: \geq 80 \%$ of normalization rate; $++: 70 \%$ of normalization rate; $+: 50 \%$ of normalization rate. An extract is considered to possess very high activity $(+++)$ if normalization $>70 \%$; high activity $(++)$ if $50<$ normalization $<70 \%$; weak activity $(+)$ if $10<$ normalization $<50 \%$; no activity $(-)$ if normalization $<10 \%(14)$.

TABLE 4: Use values of medicinal plants used in the management of sickle cell disease in Kikwit city.

\begin{tabular}{lcccc}
\hline Plant species & Local $N$ & Literature RFC & $N$ & References \\
\hline Alchornea cordifolia Müll. Arg. & 0.69 & & 0.130 & 0.087 \\
Annona senegalensis Pers & 0.71 & 2 & 0.043 & {$[14,23,31]$} \\
Bougainvillea sp comm. ex Juss & 0.22 & 1 & 0.087 & {$[14,18]$} \\
Bridelia ferruginea Benth. & 0.32 & 2 & 0.130 & {$[31]$} \\
Carica papaya L. & 0.79 & 3 & 0.087 & {$[14,31]$} \\
Ceiba pentandra (L.) Gaertn. & 0.24 & 2 & 0.043 & {$[23,31,33]$} \\
Dissotis brazzae Cogn & 0.48 & 1 & 0.087 & {$[14,31]$} \\
Hymenocardia acida Tul & 0.81 & 2 & 0.043 & {$[9]$} \\
Hypoxis angustifolia Lam. & 0.68 & 1 & 0.087 & {$[14,31]$} \\
Justicia secunda Vahl & 0.83 & 2 & 0.043 & {$[31]$} \\
Treculia africana & 0.15 & 1 & 0.130 & {$[23,31]$} \\
Vigna unguiculata (L.) Welp & 0.81 & 3 & {$[31]$} \\
Total sources & 1 & 23 & {$[14,31,33]$} \\
\hline
\end{tabular}

TABLE 5: Perimeter, surface, and radius of untreated and treated sickle RBCs with the aqueous extract of D. brazzae and A. bettzickiana leaves.

\begin{tabular}{lccc}
\hline Samples & Cellular perimeter $(\mu \mathrm{m})$ & Cellular surface $\left(\mu \mathrm{m}^{2}\right)$ & Cellular radius $(\mu \mathrm{m})$ \\
\hline Negative control & $24.9 \pm 1.1$ & $32.5 \pm 2.6$ & - \\
Positive control & $19.0 \pm 1.7$ & $25.1 \pm 1.8$ & $3.5 \pm 0.3$ \\
Extract of A. bettzickiana & $18.9 \pm 1.7$ & $24.7 \pm 2.4$ & $3.5 \pm 0.4$ \\
Extract of D. brazzae & $19.4 \pm 2.1$ & $25.3 \pm 2.0$ & $3.6 \pm 0.5$ \\
\hline
\end{tabular}

the same range to those obtained in previous studies [4-6, 23-28, 30-33]. Used software cannot calculate the radius of untreated sickle red blood cells because the shape of cells was elongated, not circular. However, in the presence of plant extracts, cell shape becomes circular, and the radius could be calculated.
Indeed, hydrophobic interactions between hemoglobin S (HbS) molecules conduct to intracellular hydrophobic interactions that induce intracellular polymerization. This hemoglobin aggregation modifies the erythrocyte shape conducting to a sickled form. Plant extracts contain molecules that can interact with $\mathrm{HbS}$ molecules and compete with 


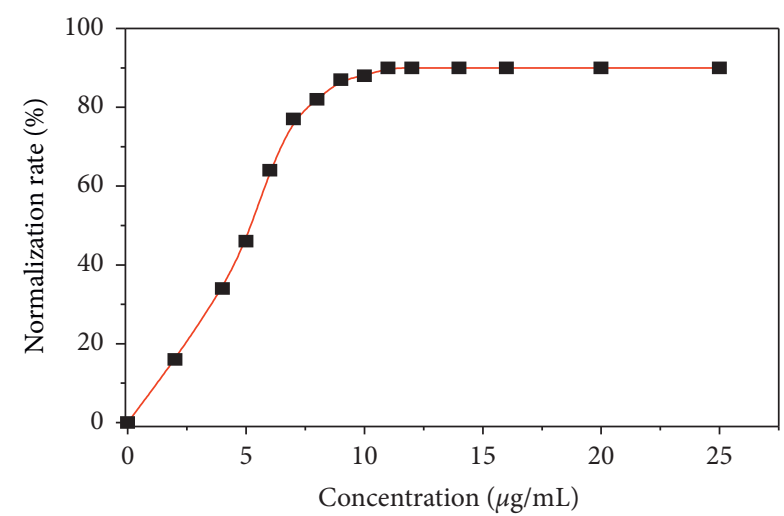

FIGURE 12: Evolution of the normalized rate of the sickle cell shape with the concentration of $D$. brazzae aqueous extracts.

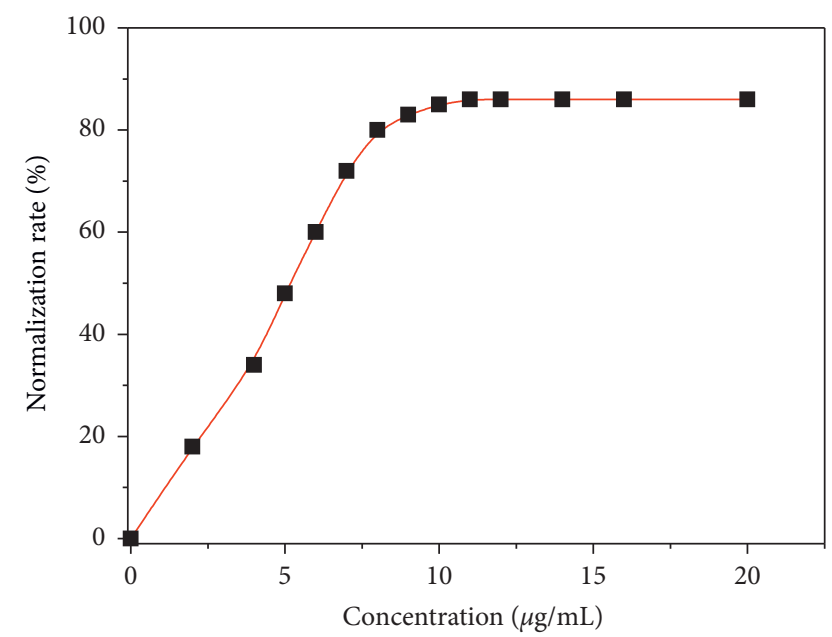

Figure 13: Evolution of the normalization rate of the sickle cell shape with the concentration of D. brazzae aqueous extracts.

their polymerization $[12,32,33]$. This permits sickle red blood cells to return to their normal biconcave form.

The normalized rate can be calculated by following the percentage of erythrocytes that regain the normal shape in function of the concentration of plant extracts. Figures 12 and 13 give an illustration of the normalization of the aqueous extract of $D$. brazzae and A. bettzickiana, respectively.

These curves show that the percentage of the drepanocytes, which return to the normal shape, increases with the extract concentration indicating that the normalization rate is dose-dependent. The minimal concentration of normalization (MCN) obtained is 0.9 and $11.0 \mu \mathrm{g} / \mathrm{mL}$ with a maximal normalization rate (NRmax) of 90 and $86 \%$ for D. brazzae and A. bettzickiana, respectively. This indicates that the aqueous extract of the two plants has very high NRmax with low MCN, but $D$. brazzae is a little more active than A. bettzickiana. The same behavior was found in other Congolese medicinal plants used in the management of sickle cell disease, but the obtained value of MCN and NRmax depends on the plant species [4, 5, 9, 23-33].

\section{Conclusion}

The traditional healers of Kikwit (DRC) use 23 plant species in the management of sickle cell disease. Eighteen plant species showed a high antisickling activity in vitro with a normalized rate of at least $70 \%$. The present results validate and support the local uses of plants in the treatment of diseases, especially sickle cell disease. Most of these plants have already been cited for their antisickling activity in other parts of the DRC and in the literature. Two species including Alternanthera bettzickiana and Dissotis brazzae deserve indepth investigations to meet scientific demands for clinical studies. Furthermore, it is crucial to isolate their bioactive compounds in order to understand their pharmacological mechanisms.

\section{Data Availability}

The data used in this study are provided and included within the article.

\section{Conflicts of Interest}

The authors declare that there are no conflicts of interest.

\section{References}

[1] B. Z. Gbolo, L. Z. Asamboa, G. N. Bongo et al., "Bioactivity and chemical analysis of Drepanoalpha: an anti-sickle cell anemia poly-herbal formula from Congo-Kinshasa," American Journal of Phytomedicine and Clinical Therapeutics, vol. 5, no. 1, pp. 1-7, 2017.

[2] B. Gbolo, D. Tshibangu, P. Memvanga et al., "Assessment of the efficacy and tolerance of drepanoalpha in the management of sickle cell disease in Kinshasa (DR Congo): about ten cases," International Journal of Medical and Pharmaceutical Case Reports, vol. 9, no. 2, pp. 1-10, 2017.

[3] B. Gbolo, D. Tshibangu, L. Asamboa et al., "Sickle cell anemia therapeutic approach based on drepanoalpha: about 34 cases," Journal of Complementary and Alternative Medical Research, vol. 4, no. 2, pp. 1-8, 2017.

[4] P. Mpiana, M. Bokota, M. Ndjele et al., "Antisickling activity of three species of Justicia from Kisangani (D.R. Congo): J. tenella, J. gendarussa and J. insularis," International Journal of Biological and Chimical Sciences, vol. 4, no. 6, pp. 19531961, 2010.

[5] P. Mpiana, L. Makelele, R. Oleko et al., "Antisickling activity of medicinal plants used in the management of sickle cell disease in the Tshopo district, DR Congo," Australian Journal of Medical Herbalism, vol. 22, no. 4, pp. 132-137, 2010.

[6] P. T. Mpiana, V. Mudogo, D. S. T. Tshibangu et al., "Antisickling activity of anthocyanins from Bombax pentadrum, Ficus capensis and Ziziphus mucronata: photodegradation effect," Journal of Ethnopharmacology, vol. 120, no. 3, pp. 413-418, 2008.

[7] K. Ngbolua, R. Herintsoa, R. Hajatiana et al., "In vitro antierythrocyte sickling effect of lunularic acid of natural origin," International Blood Research \& Reviews, vol. 4, no. 3, pp. 1-6, 2015.

[8] K. N. Ngbolua, L. E. Moke, J. K. Lumande, and P. T. Mpiana, "Canarium schweinfurthii Engl. (Burseraceae): an updated review and future direction for sickle cell disease," Journal of Advancement in Medical and Life Sciences, vol. 3, no. 3, 2015. 
[9] J. Kitadi, P. Mazasa, D. Tshibangu et al., "Anti-sickling and antioxidant activities of anthocyanins extracts from Dissotis brazzae Cogn (Melastomataceae)," Journal of Advancement in Medical and Life Sciences, vol. 3, no. 4, 2015.

[10] C. M. Mbadiko, K. Ngbolua, P. T. Mpiana et al., "Phytochemical screening and assessment of anti-sickling activity of total methanolic extracts of different organs of Curcuma longa L. (Zingiberaceae)," The Pharmaceutical and Chemical Journal, vol. 4, no. 1, pp. 32-40, 2017.

[11] D. D. Tshilanda, P. K. Mutwale, D. V. N. Onyamboko et al., "Chemical fingerprint and anti-sickling activity of rosmarinic acid and methanolic extracts from three species of ocimum from DR congo," Journal of Biosciences and Medicines, vol. 4, pp. 59-68, 2016.

[12] D. D. Tshilanda, D. N. Onyamboko, P. Babady-Bila et al., "Anti-sickling activity of ursolic acid isolated from the leaves of Ocimum gratissimum L. (Lamiaceae)," Natural Products and Bioprospecting, vol. 5, pp. 215-221, 2015.

[13] R. E. Ware, M. D. Montalembert, L. Tshilolo, and M. R. Abboud, "Sickle cell disease," The Lancet, vol. 6736, no. 17, pp. 1-13, 2017.

[14] P. T. Mpiana, D. S. T. Tshibangu, O. M. Shetonde, and K. N. Ngbolua, "In vitro antidrepanocytary actvity (anti-sickle cell anemia) of some Congolese plants," Phytomedicine, vol. 14, pp. 192-195, 2007.

[15] F. B. Piel, M. H. Steinberg, and D. C. Rees, "Sickle cell disease," The New England Journal of Medicine, vol. 376, pp. 1561-1573, 2017.

[16] K. Ngbolua, D. D. Tshilanda, D. R. Djoza et al., “Anti-sickle cell anemia and bacterial inhibitory effects of Uvariodendron molundense (Diels) R.E.Fr. (Annonaceae) from Ubangi river basin, DR. Congo," Journal of Biosciences and Medicines, vol. 5, no. 1, pp. 71-84, 2017.

[17] M. Katemo, P. T. Mpiana, B. M. Mbala et al., "Ethnopharmacological survey of plants used against diabetes in Kisangani city (DR. Congo)," Journal of Ethnopharmacology, vol. 144, no. 1, pp. 39-43, 2012.

[18] G. Bongo, C. Inkoto, C. Masengo et al., "Antisickling, antioxidant and antibacterial activities of afromomum alboviolaceum (ridley) K. Schum, Annona senegalensis pers. And mondia whitei (hook. F.) skeels," American Journal of Laboratory Medicine, vol. 2, no. 4, pp. 52-59, 2017.

[19] A. B. Nienie, P. Sivalingam, A. Laffite et al., "Microbiological quality of water in a city with persistent and recurrent waterborne diseases under tropical sub-rural conditions: the case of Kikwit city, Democratic Republic of the Congo," International Journal of Hygiene and Environmental Health, vol. 220, no. 5, pp. 820-828, 2017.

[20] The World Medical Association, "Declaration of Helsinki: ethical principles for medical research involving human subjects," pp. 1-5, 2008.

[21] F. M. Kasali, A. O. Mahano, D. S. Nyakabwa et al., "Ethnopharmacological survey of medicinal plants used against malaria in Bukavu city (D.R. Congo)," European Journal of Medicinal Plants, vol. 4, no. 1, pp. 29-44, 2014.

[22] K. Ngbolua, S. O. Mihigo, C. I. Liyongo et al., "Ethnobotanical survey of plant species used in traditional medicine in Kinshasa city (Democratic Republic of the Congo)," Tropical Plant Research, vol. 3, no. 2, pp. 413-427, 2016.

[23] P. T. Mpiana, K. T. N. Ngbolua, M. T. Bokota et al., "In vitro effects of anthocyanin extracts from Justicia secunda Vahl. on the solubility of haemoglobin $S$ and membrane stability of sickle erythrocytes," Blood Transfus, vol. 8, pp. 248-254, 2010.
[24] K. N. Ngbolua, V. Mudogo, P. T. Mpiana et al., "Evaluation de l'activité anti-drépanocytaire et antipaludique de quelques taxons végétaux de la République Démocratique du Congo et de Madagascar," Ethnopharmacologia, vol. 50, pp. 7-12, 2013.

[25] K. Ngbolua, T. Bishola, P. Mpiana et al., "Ethno-pharmacological survey, in vitro anti-sickling and free radical scavenging activities of Carapa procera DC Btem Bark (Meliaceae)," Nova Journal Of Medical And Biological Sciences, vol. 3, no. 1, pp. 1-10, 2014.

[26] K. Ngbolua, P. Mpiana, V. Mudogo et al., "Ethno-pharmacological survey and floristical study of some medicinal plants traditionally used to treat infectious and parasitic pathologies in the Democratic Republic of Congo," International Journal of Medicinal Plants Photon Foundation, vol. 106, pp. 427-432, 2014.

[27] K. Ngbolua, P. Mpiana, D. Tshibangu et al., "In vitro antisickling and radical scavenging activities of a poly-herbal formula (Drepanoalpha ${ }^{\circledR}$ ) in sickle cell erythrocyte and acute toxicity study in Wistar albino rats," European Journal of Medicinal Plants, vol. 4, no. 10, pp. 1251-1267, 2014.

[28] P. T. Mpiana, E. K. Balanganayi, A. B. Kanangila, E. M. Kalonda et al., "Activité antidrépanocytaire et thermodégradation des anthocyanes extraits de Sterculia quinqueloba et Ficus capensis," International Journal of Biological and Chemical Sciences, vol. 3, no. 3, pp. 551-560, 2009.

[29] P. Mpiana, V. Mudogo, D. Tshibangu, K. Ngbolua, D. Tshilanda, and E. K. Atibu, "Antisickling activity of anthocyanins of Jatropha curcas L," Recent Progress in Medicinal Plants, vol. 25, pp. 101-108, 2009.

[30] P. Mpiana, M. Bokota, K. Mbula et al., "Effect of anthocyanin extracts from Justicia matammensis and Justicia laxa on sickle cells," in Anthocyanins: Structure, Biosynthesis and Health Benefits, N. Motashi, Ed., no. 5, pp. 111-124, Nova Publishers, Hauppauge, NY, USA, 2012.

[31] P. Mpiana, K. Ngbolua, V. Mudogo et al., "The potential effectiveness of medicinal plants used for the treatment of sickle cell disease in the Democratic Republic of Congo folk medicine: a review," Progress in Traditional and Folk Herbal MdecineBokota, vol. 1, pp. 1-11, Daya Publishng House, New Delhi, India, 2012.

[32] P. T. Mpiana, F. M. Kasali, F. Bwirhonde, B. Z. Gbolo et al., "Acute and sub-acute oral toxicity study of Drepanoalpha ${ }^{\circledR}$ (A poly-herbal formula used in the management of sickle cell disease) in Guinea-pigs," British Journal of Pharlaceutical Research, vol. 10, no. 5, pp. 1-8, 2016.

[33] P. T. Mpiana, K. T. N. Ngbolua, and D. S. T. Tshibangu, "Les Aliments et la drépanocytose: une mini-revue," Comptes Rendus Chimie, vol. 19, no. 7, pp. 884-889, 2016. 